\title{
Sistem Informasi Manajemen Pemantauan Pembayaran Pajak Bumi dan Bangunan di Kota Tidore Berbasis Web
}

\author{
M. Fathir Abdul Gani ${ }^{(1)}$, Hans F. Wowor ${ }^{(2)}$, Feisy D. Kambey ${ }^{(3)}$ \\ Teknik Infromatika Universitas Sam Ratulangi, Manado, Indonesia. \\ fathir_aradaos@yahoo.co.id, hanswowor@unsrat.ac.id, feisykambey@unsrat.ac.id
}

\begin{abstract}
Abstrak - Pajak Bumi dan Bangunan (PBB) adalah salah satu pajak yang memberikan kontribusi besar bagi pendapatan daerah. PBB dapat dibayarkan melalui kantor kelurahan, Bank yang tercantum pada SPPT, atau instansi lain yang ditunjuk oleh pemerintah. Salah satu masalah yang dihadapi oleh pemerintah sendiri adalah sulitnya untuk mengetahui perkembangan pembayaran, realisasi penerimaan, dan capaian kinerja di tiaptiap tempat pembayaran, karna masih dilakukan dengan mekanisme manual. Sistem informasi manajemen pemantauan pembayaran pajak bumi dan bangunan yang dirancang menggunakan metode pengembangan RAD (Rapid Apllication Deployment), bahasa pemrograman yang digunakan adalah HTML, CSS, PHP dan MySQL sebagai basis datanya. Hasil akhir dari penelitian ini adalah suatu Sistem Informasi Manajemen Pemantauan Pembayaran Pajak Bumi dan Bangunan Berbasis Web yang dapat menampilkan laporan pembayaran, laporan tunggakan, dan laporan penerimaan kapanpun diperlukan.
\end{abstract}

Kata kunci : Pajak Bumi dan Bangunan, Sistem Informasi, Pemantauan, Rapid Apllication Deployment (RAD)

\section{PENDAHULUAN}

Pada era komputerisasi ini kebutuhan manusia akan informasi memacu pesatnya perkembangan teknologi di bidang informasi. Teknologi yang semakin meningkat didukung dengan sarana dan prasarana yang memadai, membuktikan bahwa kini informasi telah menjadi kebutuhan pokok dalam kehidupan manusia.

Pajak Bumi dan Bangunan (PBB) adalah Pajak Negara yang dikenakan terhadap bumi dan/atau bangunan berdasarkan Undang-undang nomor 12 Tahun 1985 tentang Pajak Bumi dan Bangunan sebagaimana telah diubah dengan UndangUndang nomor 12 Tahun 1994. Pembayaran Pajak Bumi dan Bangunan dapat dilakukan di beberapa tempat, mulai dari kantor kelurahan, Bank yang tercantum pada SPPT, atau instansi lain yang ditunjuk oleh pemerintah. Di Kota Tidore sendiri untuk pembayaran PBB Pemerintah dalam hal ini Dinas Pendapatan Daerah bekerja sama dengan pihak kelurahan sebagai pihak yang bertanggung jawab untuk melakukan pemungutan PBB di kelurahannya masing-masing.

Untuk mengetahui informasi pembayaran yang diperoleh maka pemerintah daerah khususnya Dinas Pendapatan Daerah akan melakukan pemantauan terhadap kegiatan operasional dari proses pemungutan PBB. Namun dalam pelaksanaanya, kegiatan pemantauan belum optimal dikarenakan untuk mengetahui perkembangan pembayaran, realisasi penerimaan, dan capaian kinerja masih dilakukan dengan mendatangi tiaptiap kelurahan, cara ini merupakan mekanisme manual yang masih berajalan hingga saat ini, dengan mekanisme tersebut memungkinkan terjadinya waktu kerja yang kurang efektif.

Dengan dukungan teknologi informasi yang ada sekarang ini, maka kegiatan pemantauan secara manual dapat digantikan dengan sebuah sistem informasi dengan menggunakan komputer. Selain lebih cepat dan mudah, Data perolehan PBB bisa di monitor secara real time, demikian juga data pembayaran dan tunggakan.

\section{LANDASAN TEORI}

\section{A. Sistem}

Jogiyanto (2005) Mengemukakan bahwa, sistem adalah kumpulan dari elemen-elemen yang berinteraksi untuk mencapai suatu tujuan tertentu. sistem ini menggambarkan suatu kejadian-kejadian dan kesatuan yang nyata adalah suatu objek nyata, seperti tempat, benda, dan orang-orang yang betul-betul ada dan terjadi. Sistem merupakan serangkaian prosedur yang saling berhubungan dalam melaksanakan suatu pekerjaan tertentu. Sistem terdiri dari unsur yang dapat dikenal, saling melengkapi karena satu maksud, tujuan dan sasaran.

\section{B. Informasi}

informasi adalah data yang telah diolah menjadi sesuatu yang berguna bagi penerimanya dan bertujuan untuk pengambilan keputusan atau kesimpulan. Berikut adalah beberapa definisi informasi yang dikemukakan para ahli:

1. Menurut Barry E. Cushing dalam Wahyono (2004), informasi merupakan sesuatu yang menunjukan hasil pengolahan data yang diorganisasi dan berguna kepada orang yang menerimanya.

2. Mcleod (2001), mendefinisikan bahwa informasi adalah data yang telah diolah menjadi bentuk yang memiliki arti bagi penerima dan bermanfaat bagi pengambilan keputusan saat ini atau mendatang. Sumber dari informasi adalah data. Data merupakan bentuk yang masih mentah, belum dapat bercerita banyak sehingga perlu diolah lebih lanjut. Data diolah 
melalui suatu metode untuk menghasilkan informasi. Data yang diolah melalui suatu model menjadi informasi, penerima kemudian menerima informasi tersebut, membuat suatu keputusan dan melakukan tindakan, yang berarti menghasilkan suatu tindakan lain yang akan membuat sejumlah data kembali

3. Menurut Sutabri (2012), Informasi merupakan proses lebih lanjut dari data yang sudah memiliki nilai tambah.

\section{Manajemen}

Menurut Terry (2000), Manajemen adalah suatu proses atau kerangka kerja yang melibatkan bimbingan atau pengarahan suatu kelompok orang-orang ke arah tujuan-tujuan organisasional maksud yang nyata. Ditinjau dari segi fungsinya, manajemen memiliki 4 fungsi dasar yang menggambarkan proses manajemen, semuanya terangkum sebagai berikut:

a. Perencanaan

Perencanaan melibatkan urusan memilih tugas yang harus dilakukan untuk mempertahankan tujuan organisasi, menjelaskan bagaimana tugas harus dilaksanakan, dan memberi indikasi kapan harus dikerjakan.

b. Pengorganisasian

Pengorganisasian yakni memberi tugas sebagai hasil dari tahapan perencanaan, tugas tersebut diberikan kepada beragam individu atau grup di dalam organisasi. Mengorganisir adalah untuk menciptakan mekanisme untuk menjalankan rencana.

c. Pengaruh

Pengaruh merupakan sebuah motivasi, kepemimpinan atau arah. Pengaruh dapat didefinisikan sebagai bimbingan dari aktivitas dari anggota organisasi dalam arah yang dapat membantu organisasi lebih terarah untuk mencapai hasil atau target.

d. Pengendalian

Pengendalian merupakan sejumlah peranan yang dimainkan oleh para menejer.

\section{Sistem Informasi Manajemen}

Sistem informasi manajemen menurut Jogiyanto (2005), adalah kumpulan dari manusia dan sumber daya modal di dalam suatu organisasi yang bertanggung jawab mengumpulkan dan mengolah data untuk mengahasilkan informasi yang berguna untuk semua tingkatan manajemen di dalam kegiatan perencanaan dan pengendalian. 5 aspek yang dapat dikategorikan sebagai ciri khusus bidang SIM antara lain :

a. Proses Manajemen, seperti perencanaan strategis, pengelolaan fungsi sistem informasi, dan seterusnya.

b. Proses Pengembangan, seperti manajemen proyek pengembangan sistem, dan seterusnya.

c. Konsep Pengembangan, seperti konsep sosio-teknikal, konsep kualitas, dan seterusnya.

d. Representasi, seperti sistem basis data, pengkodean program, dan seterusnya.

e. Sistem Aplikasi, seperti Knowledge Management, Executive System, dan seterusnya.
E. Pajak Bumi dan Bangunan

Pajak Bumi dan Bangunan (PBB) adalah Pajak Negara yang dikenakan terhadap bumi dan atau bangunan berdasarkan Undang-undang nomor 12 Tahun 1985 sebagaimana telah diubah dengan Undang-Undang nomor 12 Tahun 1994. PBB adalah pajak yang bersifat kebendaan dalam arti besarnya pajak terutang ditentukan oleh keadaan objek yaitu bumi/tanah dan atau bangunan. Keadaan subjek (siapa yang membayar) tidak ikut menentukan besarnya pajak.

\section{F. PHP}

Swastika (2006) mengemukakan bahwa, PHP merupakan bahasa berbentuk skrip yang ditempatkan dalam server dan diproses di server. Hasilnya akan dikirimkan ke client, tempat pemakai menggunakan browser. PHP dikenal sebagai sebuah bahasa scripting, yang menyatu dengan tag-tag HTML, dieksekusi di server, dan digunakan untuk membuat halaman web yang dinamis seperti halnya Active Server Pages (ASP) atau Java Server Pages (JSP). PHP merupakan sebuah software open source.

\section{G. HTML}

Menurut Turban (2005), HTML adalah bahasa pemrograman yang digunakan di Web dalam format dokumen dan menghubungkan dynamic hypertext ke dokumen lain yang tersimpan dalam komputer lain. HTML adalah bahasa yang sangat tepat dipakai untuk menampilkan informasi pada halaman web. HTML menampilkan informasi dalam bentuk hypertext dan juga mendukung sekumpulan perintah yang dapat digunakan untuk mengatur tampilnya informasi tersebut.

\section{H. MySQL}

MySQL menurut Bunafit (2004), merupakan pemrograman/sistem manajemen basis data (kumpulan data yang terstruktur) yang menggunakan basis bahasa SQL (Structured Query Language). MySQL merupakan sistem manajemen basis data yang dapat diandalkan dan penggunaannya mudah untuk dipahami. MySQL didesain untuk menangani basis data yang besar dengan cepat, memiliki tingkat keamanan dan konektivitas yang tinggi.

Penerapan basis data dalam sistem informasi disebut dengan Database System. Sistem basis data (Database System) adalah suatu sistem informasi yang mengintegrasikan kumpulan dari data yang saling berhubungan satu dengan yang lainnya dan membuatnya tersedia untuk beberapa aplikasi yang bermacam-macam di dalam suatu organisasi. Basis data yang sekarang paling banyak dipakai adalah basis data relasi. Basis data relasi biasanya disusun dalam bentuk kolom-kolom dan baris-baris. Salah satu basis data relasi adalah MySQL. MySQL merupakan salah satu basis data yang sering digunakan sebagai penyimpanan data suatu sistem informasi. 


\section{Metodologi Penelitian}

Dalam penelitian ini penulis menggunakan metode Rapid Application Development (RAD), metode RAD terdiri dari 3 fase, yaitu Requirements Planning (Perencanaan Persyaratan), RAD Design Workshop, Implementation (Penerapan), berikut adalah gambar dari tahapan pengembangan metode RAD.

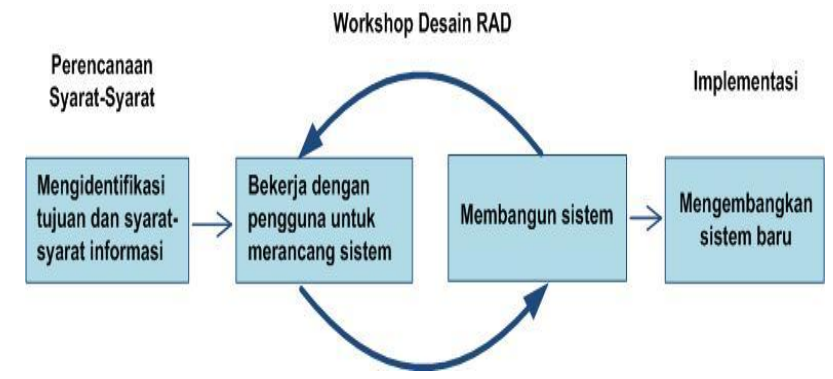

Gambar 1 Tahapan Pengembangan Metodologi RAD

\section{A. Perencanaan Persyaratan}

Tahap perencanaan persyaratan bertujuan untuk mengidentifikasi kebutuhan pengguna, dan spesifikasi sistem yang akan dibangun melalui hasil obsevasi lapangan, studi pustaka dan pengumpulan data dari pengguna, sehingga sistem yang akan dibuat sesuai dengan kebutuhan pengguna.

Data yang diperoleh dengan metode wawancara dilakukan dengan Mewawancarai Sekretaris Dinas Pendapatan daerah Kota Tidore mengenai kubutuhan sistem yang menjadi acuan dalam penelitian ini. Tahap perencanaan persyaratan tersebut dijelaskan dalam tabel problem statement matrix yang dapat dilihat pada table 1 .

Tabel 1 Problem Statement Matrix

\begin{tabular}{|l|l|}
\hline $\begin{array}{l}\text { The } \\
\text { problem } \\
\text { of }\end{array}$ & $\begin{array}{l}\text { Proses bisnis yang masih menggunakan } \\
\text { sistem manual yang tidak efisien dan } \\
\text { memiliki banyak kekurangan }\end{array}$ \\
\hline Affects & Proses pemantauan pembayaran \\
\hline $\begin{array}{l}\text { The } \\
\text { impact of } \\
\text { which } \text { is }\end{array}$ & Sulit untuk melakukan pemantauan \\
\hline $\begin{array}{l}\text { A } \\
\text { successful } \\
\text { solution } \\
\text { would be }\end{array}$ & $\begin{array}{l}\text { Merancang sebuah sistem informasi pajak } \\
\text { bumi dan banguan berbasis web yang } \\
\text { memiliki database sendiri dan terintegrasi } \\
\text { dengan tiap-tiap tempat pembayaran } \\
\text { sehingga dapat mempermudah proses } \\
\text { pemantauan pembayaran }\end{array}$ \\
\hline
\end{tabular}

B. RAD Design Workshop (Pemodelan)

Tujuan dari tahap ini yaitu merancang semua kegiatan dalam arsitektur sistem secara keseluruhan dengan melibatkan identifikasi dan deskripsi abstraksi sistem perangkat lunak yang mendasar dan hubungan-hubungannya. Fase ini digambarkan dengan deskripsi proses bisnis, use case diagram, activity diagram dan rancangan storyboard.
Proses Bisnis

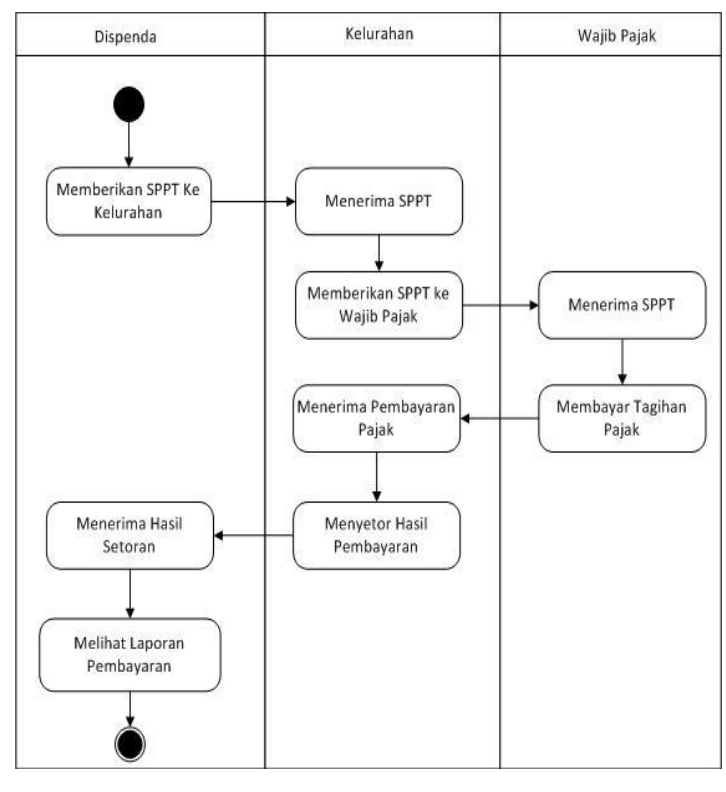

Gambar 2 Proses Bisnis

Use case Diagram

Use case diagram adalah diagram yang menggambarkan interaksi antara sistem dengan hal-hal eksternal sistem dan user. Secara grafis menggambarkan siapa yang menggunakan sistem dan seperti apa user diharapkan berinteraksi dengan sistem tersebut. Use case diagram sistem pemantauan pembayaran PBB dapat dilihat pada gambar 3

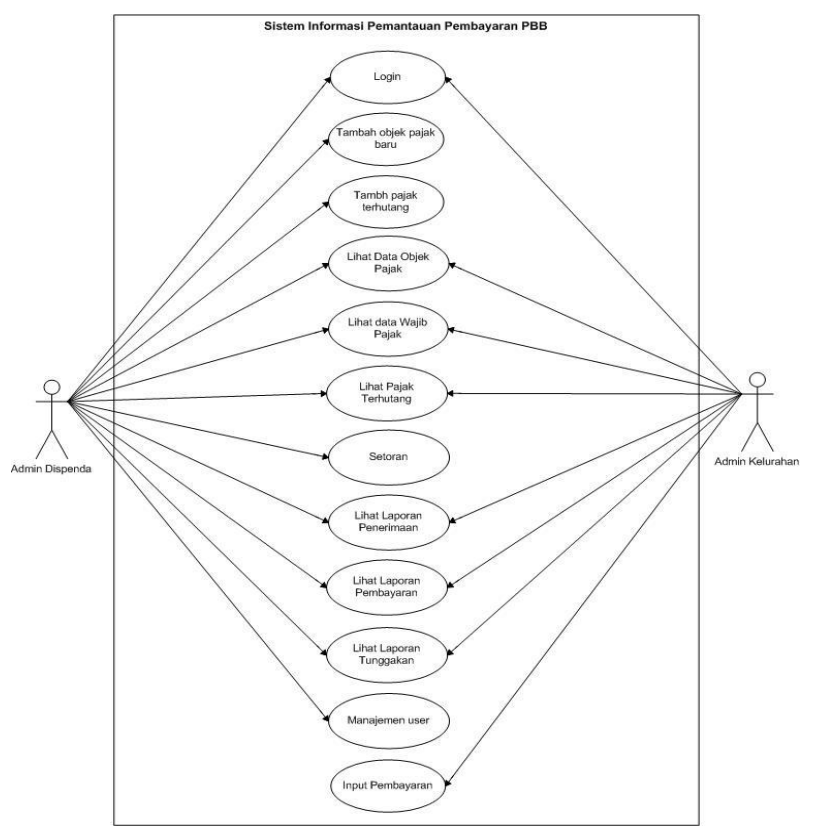

Gambar 3 Use Case Diagram

Activity Diagram

Activity diagram adalah diagram yang menggambarkan alur dari aktivitas use case dan dapat diterapkan dalam model logika dengan sistem. Activity diagram sistem pemantauan pembayaran PBB dapat dilihat pada gambar 4 


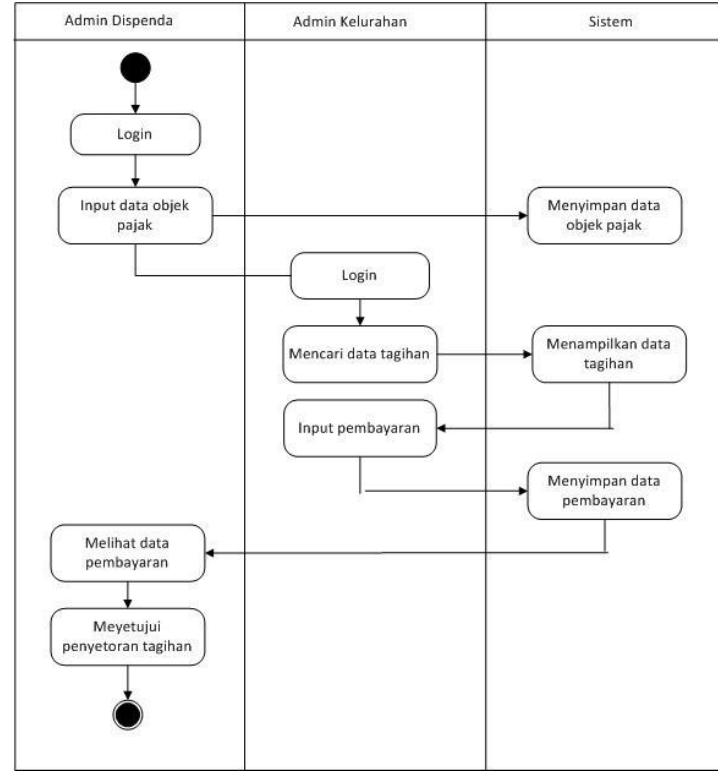

Gambar 4 Activity Diagram

\section{Storyboard}

\section{Stroryboard Halaman Login}

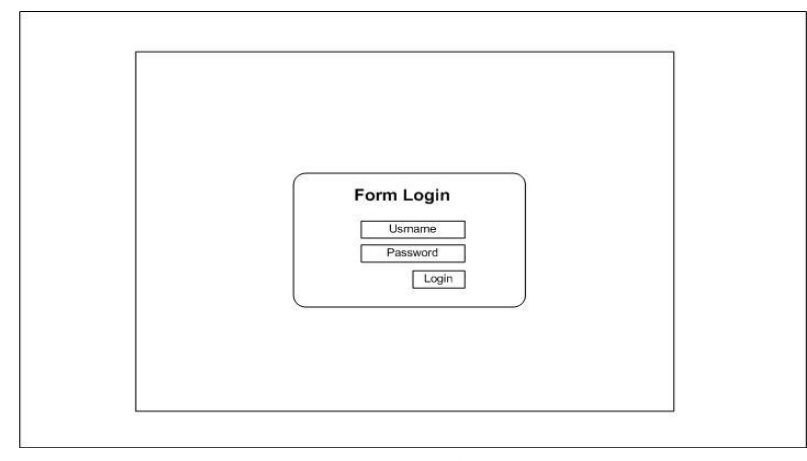

Gambar 5 Storyboard Halaman Login

Gambar 5 adalah storyboard halaman login terdapat form untuk mengisi username dan password serta tombol login untuk mengeksekusi username dan password.

\section{Stroryboard halaman admin Dispenda}

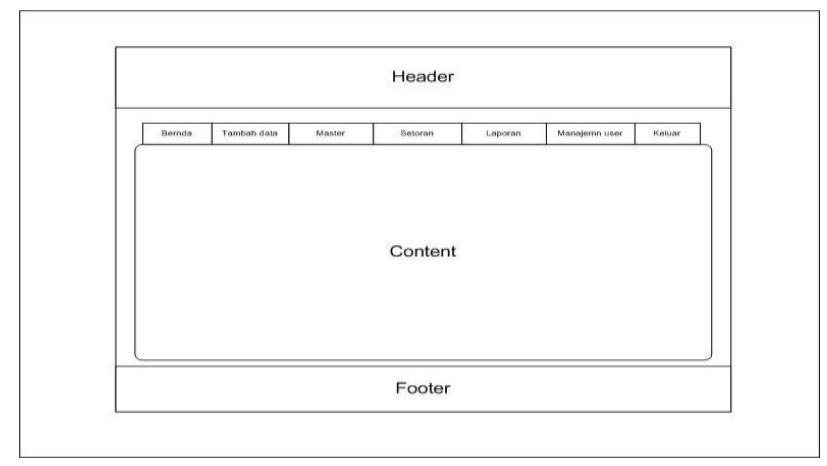

Gambar 6 Storyboard Halaman Admin Dispenda
Gambar 6 adalah stroryboard halaman utama admin Dispenda. terdapat bebrapa menu yaitu beranda, tambah data, master, setoran, laporan, manajemen user dan keluar.

Stroryboard halaman tambah objek pajak

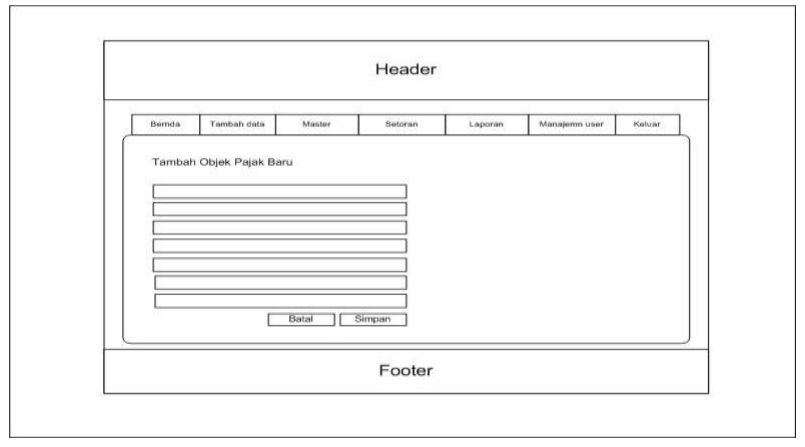

Gambar 7 Strorybaord Halaman Tambah Objek Pajak

Gambar 7 adalah stroryboard Halaman tambah objek pajak terdapat form untuk menambah data pajak yang belum terdaftar dalam database seperti data wajib pajak, data objek pajak, dan data kelengkapan berkas.

C. Implementasi

Tahap ini dilakukan konstruksi sistem dan penerapan metode yang diadaptasikan dengan proses seleksi dalam pemrograman terhadap hasil analisa kebutuhan sistem dan akan dijelaskan dalam tahap implementasi basis data. Database ini dirancang menggunakan DBMS MySQL. Gambar 8 adalah skema dari tabel-tabel database pbb.

\begin{tabular}{|c|c|c|}
\hline vo pbb tb_wajib_pajak & yolpbbtb_sppt & Vo pbb kelas_bumi \\
\hline npwp : bigint(40) & \# npwp : bigint(40) & o id_kls_bumi : int(5) \\
\hline (3) nama_wp : varchar(50) & \# nop : bigint(40) & $\#$ \# id_kel_bumi : int(11) \\
\hline (1) alamat_wp : varchar(50) & \# luas_bumi : int(11) & kls_bumi : varchar(11) \\
\hline (i) jekel : $\operatorname{varchar}(10)$ & \# id_kls_bumi : int(11) & \# nilaijual_bumi : int(20) \\
\hline (1) pekerjaan : varchar(20) & \# luas_bang: int(11) & \\
\hline (a) no hp : varchar(20) & \# id_kls_bang: int(11) P & vo pbb.kelompok_bumi \\
\hline v pbb_tb_pembayaran & of pbbttb_objek_pajak & $\begin{array}{l}\text { a id_kel_bumi : int(5) } \\
\text { a kel_bumi : varchar(5) }\end{array}$ \\
\hline id_bayar: int(10) & on : bigint(40) & \\
\hline \# npwp : bigint(40) & G lokasi_op : varchar(50) & vo pbb kelas_bangunan \\
\hline $\begin{array}{l}\text { \# nop : bigint(40) } \\
\text { \# pbb pokok : int(20) }\end{array}$ & \# id_kec : int(5) & o id_kls_bang: int(11) \\
\hline $\begin{array}{l}\text { \# pbb_pokok: int(20) } \\
\text { nt tahun_pajak : year(4) }\end{array}$ & \# id_kel: int(5) & \# id_kel_bang: int(11) \\
\hline (1) jatuh_tempo: date & vo pbb kecamatan & $\begin{array}{l}\text { 1) kls_bang: varchar(5) } \\
\text { \# nilaijual_bang: int(20) }\end{array}$ \\
\hline \# denda : int(20) & id_kec : int(5) & \\
\hline $\begin{array}{l}\text { \# total_bayar: int(20) } \\
\text { nt tanggal : date }\end{array}$ & (1) nama_kec : varchar(20) & v obb_kelompok_bangunan \\
\hline & vo pbb kelurahan & $\begin{array}{l}8 \text { id_kel_bang: int(5) } \\
\text { kel bang: varchar(5) }\end{array}$ \\
\hline vo pbb berkas & $\#$ id_kec : int(5) & \\
\hline id_berkas : int(10) & (2) id_kel: int(5) & vo pbb tb_login \\
\hline \# npwp : bigint(30) & (1) nama_kel: varchar(20) & (2) kode_user: int(20) \\
\hline 自 fc_ktp: varchar(10) & & \# id_kec: int(11) \\
\hline 目 fc_npwp: varchar(10) & & \# id_kel: int(20) \\
\hline 目 fc_sertifikat_tanah: $\operatorname{varchar}(10)$ & & (8) username : varchar(50) \\
\hline 目 fc_imb : varchar(10) & & (i) password : varchar(50) \\
\hline 目 surat_ket_lurah : varchar(10) & & (3) nama_lengkap : varchar(100) \\
\hline If fc_akta_jual_beli : varchar(10) & & \\
\hline
\end{tabular}

Gambar 8 Skema Tabel Database pbb 


\section{HASIL}

Tahap ini menjelaskan hasil dari perancangan yang dilakukan berdasarkan tujuan awal yaitu membuat suatu sistem informasi manajemen pemantauan pembayaran pajak bumi dan bangunan berbasis web.

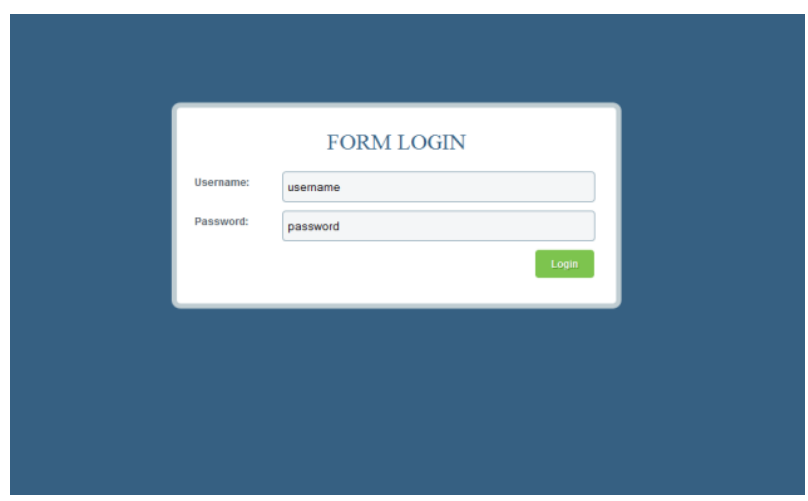

Gambar 9 Halaman Login

Gambar 9 Halaman login adalah halaman awal yang ditampilkan saat pengguna mengakses sistem, Halaman login digunakan untuk membatasi hak akses pengguna sistem karena setiap pengguna memiliki hak akses masing-masing.

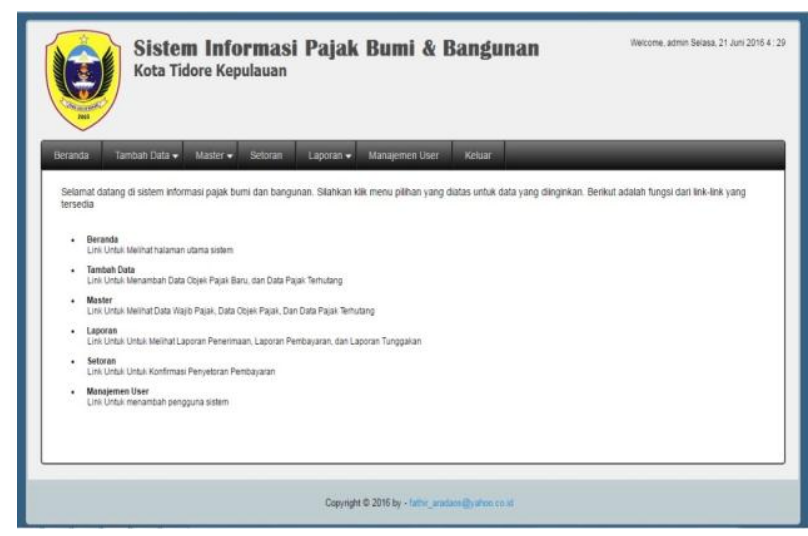

Gambar 10 Tampilan Halaman Admin Dispenda

Gambar 10 Halaman admin Dispenda adalah halaman yang digunakan oleh admin Dispenda untuk mengolah data ketetapan pajak, admin Dispenda memiliki hak akses untuk menambah data ketetapan pajak, lihat data, lihat data pembayaran, data tunggakan, membuat rekap pembayaran, lihat data penerimaan dan manajemen user.

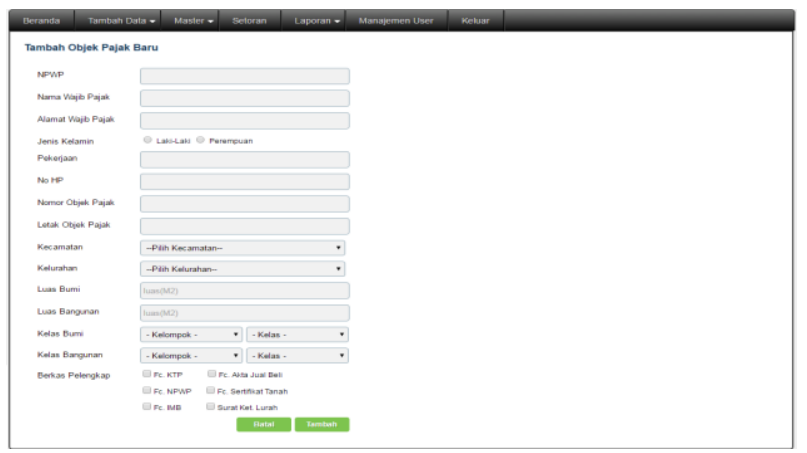

Gambar 11 Tampilan Halaman Tambah Objek Pajak
Gambar 11 adalah halaman tambah objek pajak yang belum terdaftar pada database. Data yang dimasukan adalah data-data wajib pajak, data-data objek pajak, dan klsifikasi dari objek pajak tersebut.

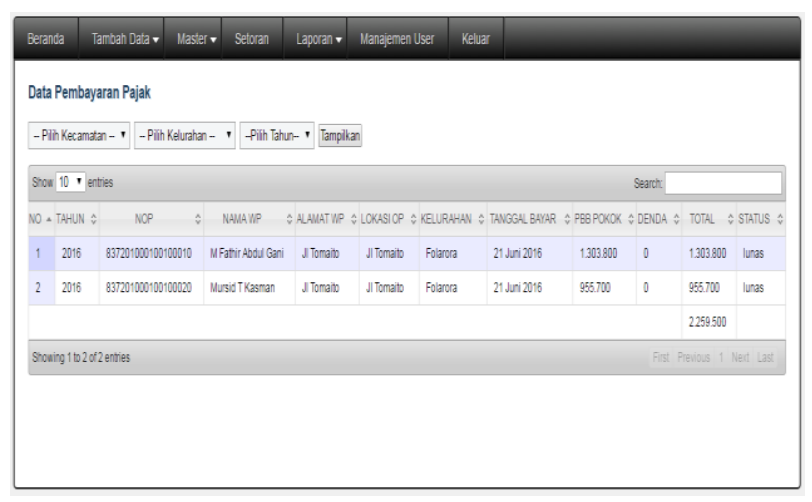

Gambar 12 Halaman Login

Gambar 12 adalah tampilan halaman laporan pembayaran yang menampilkan data-data wajib pajak yang telah melakukan pembayaran.

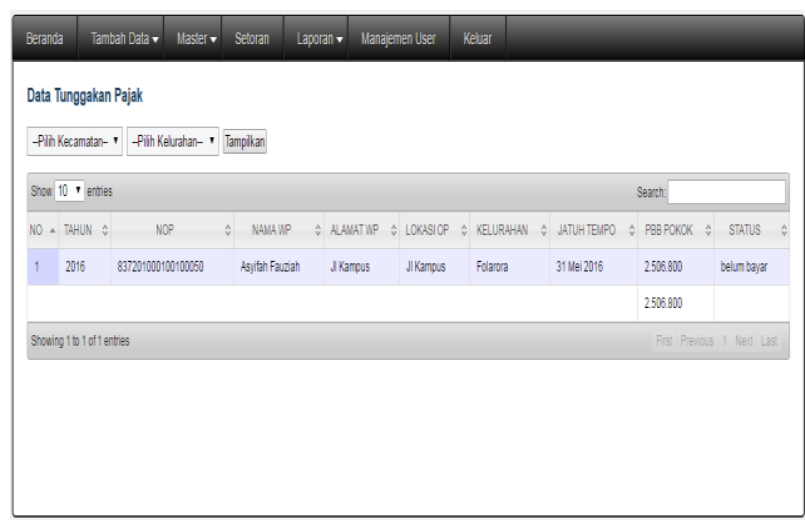

Gambar 13 Halaman Laporan pembayaran

Gambar 13 adalah tampilan halaman laporan tunggakan, halaman ini menampilkan data wajib pajak yang telah melewati tanggal jatuh tempo dan belum melakukan pembayaran.

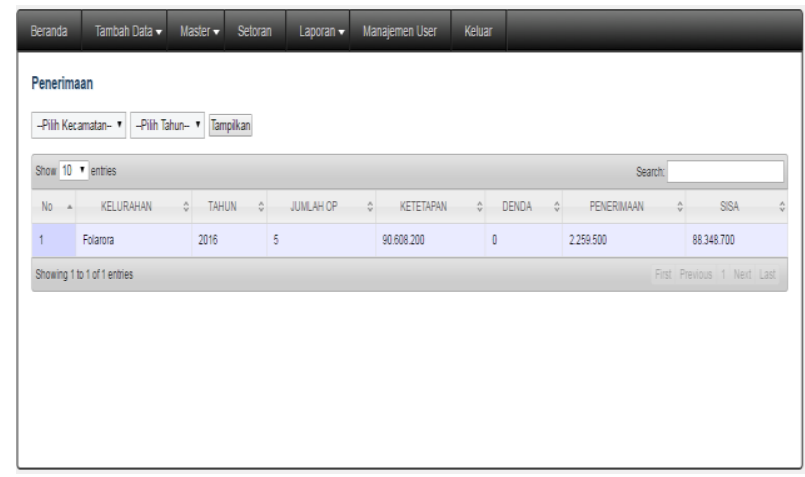

Gambar 14 Halaman Laporan Tunggakan 
Gambar 14 adalah tampilan halaman penerimaan tiap-tiap kelurahan. Pada halaman penerimaan terdapat beberapa data seperti jumlah SPPT, jumlah ketetapan PBB, jumlah denda, total, jumlah penerimaan, dan sisa yang belum dilunasi per kelurahan.

\section{PENUTUP}

\section{A. Kesimpulan}

Berdasarkan hasil dan pembahasan yang dilakukan pada bab sebelumnya dapat diperoleh kesimpulan bahwa:

1. Penelitian ini menghasilkan sebuah sistem informasi berbasis web yang dapat menampilkan data pembayaran, data tunggakan, dan penerimaan yang diperoleh tiap-tiap kelurahan secara real time.

2. Sistem informasi yang dibangun adalah aplikasi multiuser yang bisa digunakan oleh Dispenda dan Kelurahan.

3. Dalam perancangan sistem informasi pemantaun pembayaran pajak bumi dan bangunan berbasis web ini sangat diperlukan kemampuan developer dalam menguasai bahasa pemrograman web seperti PHP, HTML, CSS dan javascript agar sistem dapat diselesaikan dengan lebih efisien baik dari segi waktu B. Saran perancangan maupun kode sumber sistem.

Sistem informasi ini dapat dikembangkan dengan menambahkan fungsionalitas SMS Gateway kepada wajib pajak agar bisa mengetahui tanggal jatuh tempo pembayaran, jumlah pbb pokok, dan denda yang harus dibayar.

\section{DAFTAR PUSTAKA}

[1] Bunafit, N. 2004, Aplikasi Pemrograman Web Dinamis dengan PHP dan MySQL, Gava Media, Yogyakarta.

[2] Jogiyanto, 2005, Analisa dan Desain Sistem Informasi: Pendekatan Terstruktur Teori dan Praktik Aplikasi Bisnis, ANDI, Yogyakarta.

[3] George, R. T. 2000, Prinsip-Prinsip Manajemen. (edisi bahasa Indonesia). PT. Bumi Aksara: Bandung.

[4] McLeod, R. 2001, Sistem Informasi, Edisi 7 Jilid 2. Prenhallindo. Jakarta.

[5] Sutabri, T. 2012, Analisis Sistem Informasi Penerbit Andi, Yogyakarta.

[6] Swastika. 2006, Dasar-dasar Pengenalan PHP Untuk Orang Awam, Andi Publisher, Jakarta.

[7] Turban, 2005. Decision Support System and Intelligent System Edisi Bahasa Indonesia. Jilid 1. Yogyakarta : ANDI
[8] Wahyono, 2004, Sistem Informasi Konsep Dasar, Analisis Desain dan Implementasi, Graha Ilmu, Yogyakarta.

[9] Undang-undang Nomor: 12 Tahun 1994, Tentang Pajak Bumi dan Bangunan.

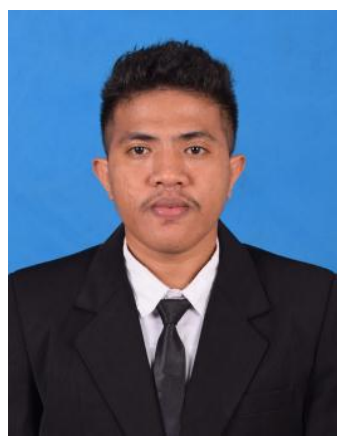

Sekilas dari penulis dengan nama lengkap M. Fathir Abdul Gani, lahir pada tanggal 23 Desember 1992 di Tidore. Dengan pendidikan pertama di SD Negeri Soadara, melanjutkan ke SMP Negeri 1 Tidore, dan pada tahun 2007 melanjutkan ke SMA Muhammadiyah 3 Tidore. Setelah lulus pada tahun 2010 penulis melanjutkan ke Perguruan Tinggi tepatnya di Universitas Sam Ratulangi Manado, Fakultas Teknik, Jurusan Elektro, Program Studi Teknik Informatika. Penulis membuat skripsi untuk memenuhi syarat sarjana (S1) dengan judul Sistem Informasi Manajemen Pemantauan Pembayaran Pajak Bumi dan Bangunan di Kota Tidore Berbasis Web yang di bimbing oleh dua dosen Teknik Informatika yaitu Ir. Hans F. Wowor, M.Kom dan Feisy D. Kambey ST, MT sehingga pada tanggal 09 Agustus 2016 penulis resmi lulus di Teknik Informatika Universitas Sam Ratulangi Manado. 